\title{
ВИКОРИСТАННЯ ОСВІТНІХ ЕЛЕКТРОННИХ РЕСУРСІВ У ПРОЦЕСІ ВИКЛАДАННЯ УКРАЇНСЬКОЇ МОВИ
}

\section{Ільчук В. В.}

\section{ВСТУП}

У сучасному суспільстві, коли інформація розглядається як вища цінність, а інформаційна культура людини - визначальний фактор їхньої професійної діяльності, висуваються нові вимоги до системи освіти, відбувається істотне підвищення іiі статусу. Кожній людині необхідно постійно підвищувати рівень своєї освіти для забезпечення успішності. Підвищення ефективності, адаптивності та змістовності навчального процесу досягається шляхом комплексного використання різних програмних і технічних засобів, а також застосування прийомів іметодів активного навчання. Успіх учнів безпосередньо залежить від якості роботи вчителя, від того, наскільки він здатний адаптуватись до потреб сьогодення. Безсумнівно, використання електронних ресурсів (ЕР) безпосередньо відповідає вимогам модернізації освіти. Педагогічні технології не залишилися осторонь від загального процесу комп'ютеризації. Електронні підручники, електролекції, віртуальні екскурсії, програми-репетитори, довідники, енциклопедії, уроки в електронному вигляді i методичні розробки до них - широкий інтерактивний світ можливостей для успішного навчального процесу.

Використання нових електронних ресурсів у навчанні дає змогу розглядати школяра як центральну фігуру освітнього процесу, що веде до зміни взаємовідносин між його суб'єктами. У результаті вчитель вже не виступає основним джерелом інформації, а займає позицію людини, що організовує самостійну діяльність учнів і керує нею. Його основна роль полягає тепер у постановці цілей навчання, організації умов, необхідних для успішного вирішення освітніх завдань.

Принципове нововведення, яке вноситься комп'ютером в освітній процес, - інтерактивність, що дає змогу розвивати активно-діяльнісні форми навчання. Тому, з нашої точки зору, використання електронних ресурсів у навчальному процесі, в т.ч. при викладанні української мови, $\epsilon$ актуальною проблемою сучасної шкільної освіти. Необхідно розширювати кругозір учнів, підвищувати рівень їхньої культурної освіти, розвивати мовні та комунікативні навички і вміння. Сучасний урок цінний не стільки отриманою інформацією, скільки навчанням у процесі його прийомів роботи 3 інформацією: пошуку, 
систематизації, обміну, естетичного оформлення результатів. Тобто комп'ютер $\epsilon$ засобом самоконтролю, тренажу знань, презентації результатів власної діяльності.

\section{1. Особливості використання електронних ресурсів \\ у процесі викладання української мови}

Нині змінюється мета і завдання, що стоять перед сучасною освітою, акцент переноситься із «засвоєння знань» на формування «компетентності». Можна погоджуватися 3 вимогами ринку і суспільства, що висуваються до освіти, чи ні, але безсумнівним $\epsilon$ те, що освоєння учнями сучасних технологій, практична спрямованість отриманих знань, вміння ставити мету, висувати гіпотезу, шукати шляхи вирішення проблеми i робити висновки - компетенції, які стають життєво необхідними.

Нині від випускників шкіл потрібні не тільки знання різноманітних наук, але й володіння якостями вільної, творчої та відповідальної особистості, здатної оптимально будувати своє життя в надзвичайно мінливому інформаційному соціумі. У цих умовах стає дедалі очевиднішим, що традиційна освіта, яка орієнтована на пряму передачу еталонних знань, вже не в повній мірі здатна вирішувати поставлені перед нею задачі. Виникла потреба в новій моделі навчання, побудованій на сучасних електронних ресурсах, що реалізує принципи особистісно-орієнтованої освіти.

Переваги використання електронних ресурсів на уроках зображені на рис. 1.

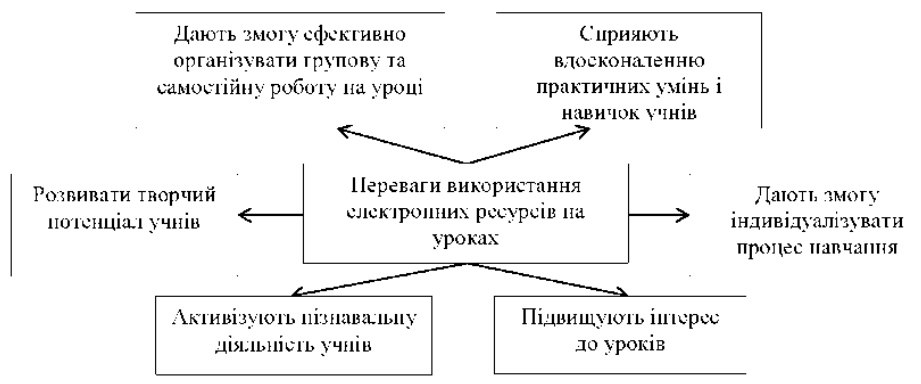

Рис. 1. Переваги використання електронних ресурсів на уроках

Джерело: авторська розробка 
Недоліками та проблемами застосування електронних ресурсів $€$ такі :

- значно більше часу потрібно для підготування уроку з використанням EP;

- недостатня комп'ютерна грамотність як учнів, так і вчителів;

- не вистачає комп'ютерного часу на всіх;

- при недостатній мотивації до роботи учні часто відволікаються на ігри, музику, перевірку характеристик ПК.

Використання EP на уроках української мови дає змогу урізноманітнити форми роботи, діяльність учнів, активізувати увагу, підвищує творчий потенціал особистості. Побудова схем, таблиць у презентації дає змогу економити час, естетичніше оформити матеріал. Завдання 3 подальшою перевіркою активізують увагу учнів, формують орфографічну пильність. Використання кросвордів, ілюстрацій, малюнків, різних цікавих завдань, тестів, виховують інтерес до уроку, роблять його більш цікавим ${ }^{2}$.

Електронну техніку можна використовувати на різних етапах уроку 3 української мови: орфографічна розминка, закріплення нової теми, проведення самостійної роботи. При цьому техніка для учня починає виконувати такі функції, як учитель, робочий інструмент, об'єкт навчання.

Зазначимо, що методика викладання української мови 3 використанням комп'ютера як електронного ресурсу дає змогу інтенсифікувати процес навчання (рис. 2).

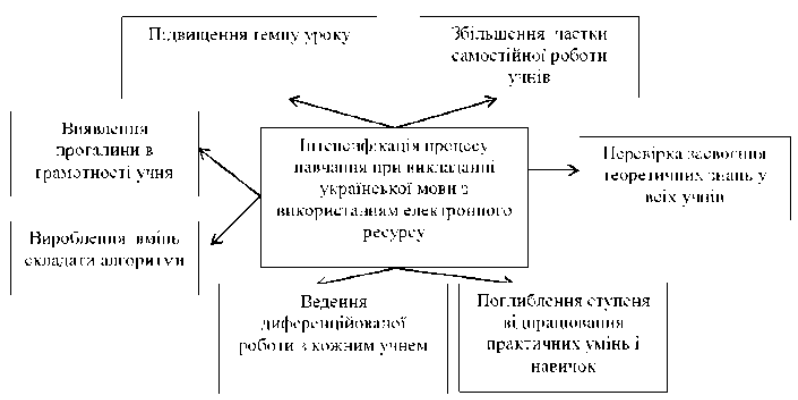

Рис. 2. Інтенсифікація процесу навчання при викладанні української мови з використанням електронного ресурсу

Джерело: авторська розробка

${ }^{1}$ Шелехова Г. Використання комп'ютерних технологій на уроках української мови. Украӥнська мова і література в школі. 2006. № 8. С. 4-8.

${ }^{2}$ Сороко Н.В. Дидактичні функції інформаційних і комунікаційних технологій у професійній діяльності вчителя-словесника. URL: http://www.nbuv.gov.ua/ejournals/IT ZN/em5/emg.html (дата звернення: 22.01.2020). 
До головних дидактичних функцій, які реалізуються за допомогою ЕР на уроках української мови, належать ${ }^{3}$ :

- пізнавальна (використовуючи комп'ютерні технології та інтернет, можна отримати будь-яку необхідну інформацію, як ту, що зберігається на жорсткому диску власної комп'ютерної бази, так і розміщену на відповідних сторінках інтернету);

- розвивальна (робота 3 різноманітними комп'ютерними програмами, сприяє розвитку таких необхідних пізнавальних процесів, як сприйняття, логічне мислення, пам'ять, уява);

- дослідницька (у школярів 3'являється змога взяти участь у роботі пошукових груп, інтернет-конкурсах, виконувати творчі роботи різних видів, створювати власні творчі проекти, розробляти доповіді, реферати, учнівські презентації, публікації, дослідити певні проблемні питання);

- комунікативна (під час обміну інформацією між учнями створюється певна віртуальна єдність, у всіх $\epsilon$ реальна змога увійти на сайти популярних сучасних науковців; вони мають змогу зіставити різні погляди, давати їм оцінку, формувати свої позиції).

Варто зазначити правила, яких варто дотримуватися під час викладання української мови з використанням $\mathrm{EP}^{4}$ :

1) головний успіх проведення уроку - це правильно поставлена мета, сформовані цілі уроку;

2) варто критично відбирати інформацію. Дидактичний матеріал має бути вмотивований змістом освітніх потреб;

3) продуктивна робота на такому уроці вимагає від вчителя чіткої організації своїх дій і чітко поставлених завдань школярам.

Індивідуалізація навчання покращує якість підготовки. Це досягається шляхом живого зворотного зв'язку, який встановлюється в процесі діалогу школяра $з$ персональним комп'ютером. Залежно від характеру відповідей на контрольні питання комп'ютер може запропонувати запитання, підказати або сповільнити темп навчання. Під час контрольних робіт, тестів, самостійних робіт кожен учень відповідає на ці завдання і самостійно отримує на екрані результат своєї відповіді. Відбувається відкрита, об'єктивна оцінка знань учнів. Це дуже важливо для дитини. Вона бачить, що оцінка не залежить від бажання вчителя, а оцінюються іiї реальні знання і вміння. Зникає страх отримання оцінки. Учень може переглянути відсоток і якість своїх знань 5 .

${ }^{3}$ Орлова О.І. Компетентнісне навчання за допомогою IКТ на уроках української мови та літератури. URL: http://5fan.ru/download.php (дата звернення: 20.01.2020).

${ }^{4}$ Ніколаєнко Т.М. Використання IКТ на уроках української мови та літератури. URL: https://vseosvita.ua/library (дата звернення: 19.01.2020).

5 Зиньковська 3.О. Психолого-педагогічні аспекти використання мультимедійних засобів навчання. Класному керівнику для роботи . 2013. № 7(55). С. 6-12. 
Також комп'ютер має досить широкі можливості для створення сприятливих умов роботи з опанування орфографічних (пунктуаційних) правил. У навчальних програмах можуть бути використані різноманітні форми наочності, які сприяють різним способам організації та подання теоретичного матеріалу у вигляді таблиць, схем, опорних конспектів. Демонструється не лише статична інформація, але і різні мовні явища в динаміці із застосуванням кольору, графіки, ефекту мерехтіння, звуку, піктографії (це якісно новий рівень застосування пояснювальноілюстративних і репродуктивних методів навчання) ${ }^{6}$.

Але відомо, що для грамотного письма буде замало знань зорфографічних i пунктуаційних правил. Головним завданням $€$ вироблення «автоматизованої грамотності», яка має стати підсвідомою навичкою. Саме в цьому ідопомагає комп'ютер. У процесі роботи учнів із комп’ютером підвищується їх мотивація, з'являються подібні навички і вміння. Учень захоплено працює 3 машиною, не бойться завдань зростаючої складності, виконує набагато більший обсяг роботи за урок, своєчасно коригуючи допущені помилки.

За допомогою комп'ютера можна організувати виконання відомих типів вправ (вставка орфограм, розстановка розділовихзнаків, редагування текстів та ін.). Особливо ефективне використання комп'ютера для тренінгу і контролю засвоєних знань і формування навичок учнів.

3 огляду на вищезазначене, використання електронних та мультимедійних ресурсів на уроках української мови дає простір для реалізації можливостей кожної дитини, робить навчання успішним і комфортним, особистісно-орієнтовним і мобільним, а також оптимізує навчальний процес.

Використання електронних ресурсів на уроках української мови дає змогу урізноманітнити форми роботи, діяльність учнів, активізувати увагу, підвищує творчий потенціал особистості. Побудова схем, таблиць, презентацій дає змогу економити час, більш естетично оформити матеріал. Використання кросвордів, ілюстрацій, малюнків, різних цікавих завдань, тестів виховує інтерес до уроку, робить його більш захоплюючим.

Мультимедійні ресурси $є$ ефективною освітньою технологією завдяки властивим їй якостям інтерактивності, гнучкості, інтеграції інформації цифрового характеру (тексти, графіка, анімація), візуального зображення (відео, фотокартки, картинки), звуку (мова, музика). Імітаційне моделювання 3 аудіовізуальним зображенням допомагає замість

6 Гулак О.А. Роль сучасних комп'ютерних та педагогічних технологій у підвищенні ефективності та результативності урочної діяльності учнів. URL: http://ru.osvita.ua/school/lessons_summary/edu_technology/44358/ (дата звернення: 24.01.2020) 
абстрактного опису дати адекватне уявлення про реальні чи навіть уявні речі. Застосування мультимедійних проектів, до якого входять документи, фото, таблиці, ілюстрації, аудіо- та відеофрагменти, скомпоновані відповідно до циклу уроків з української мови за розділами, є яскравим, динамічним, результативним, цікавим для учнів, а тому ефективним для засвоєння знань ${ }^{7}$.

У мультимедійному форматі досить вдало і ефективно представлена давно відома форма перевірки знань - самодиктант. На дошці - текст із пропущеними буквами та розділовими знаками - в кожного учня такий самий друкований текст. У процесі роботи учні мають пояснити вживання букв і розділових знаків, роблячи на дошці відповідні записи ${ }^{8}$.

Роль інтерактивних мультимедійних ресурсів підвищується у процесі реалізації проблемного діяльнісного навчання української мови на етапі пояснення, це можуть бути: віртуальні уроки, електронні слайди з таблицями, текстами-прикладами, ілюстрації та анімації, відеофрагменти, аудіозаписи під час презентації.

Наприклад, на електронних слайдах можна показувати завдання для виконання (рис. 3).

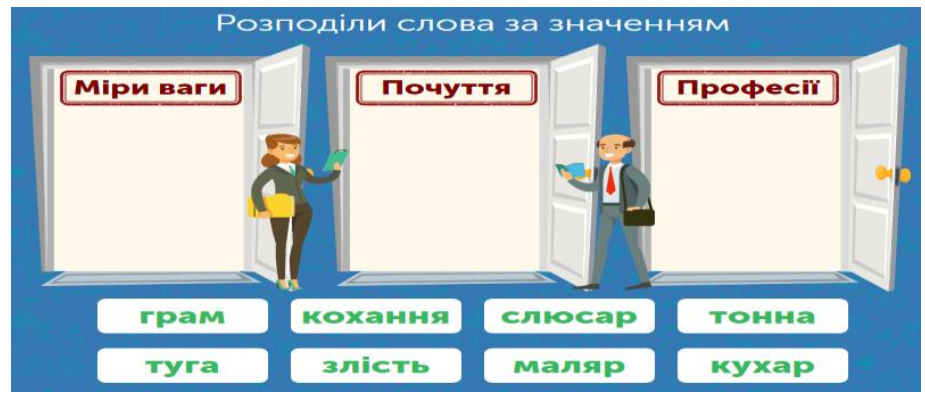

Рис. 3. Завдання з української мови

Так, різні інформаційні матеріали стимулюють увагу за рахунок зорового і слухового аналізаторів. В учнів підвищується зацікавленість до вивчення української мови, швидше розвиваються навички самостійності. Різноманітні електронні матеріали на уроках дають

7 Дементієвська Н.П., Морзе Н.В. Комп’ютерні технології для розвитку учнів та вчителів. Інформаційні технології $i$ засоби навчання : збірник наук. праць. Київ : Атака, 2005. С. 76-95.

${ }^{8}$ Гримальська А.О. Використання можливостей інформаційно-комунікаційних технологій для підвищення якості навчання української мови і літератури. Таврійський вісник освіти. 2016. № 4 (56). С. 23-27. 
змогу здійснювати швидку зміну одного виду діяльності іншим. Використання комп'ютера дає змогу розширити творчі можливості вчителя, робити уроки більш інтенсивними, цікавими та різноманітними. Створення слайд-фільму, електронного додатку до уроку, збагачує професійну палітру вчителя. Звичайно, підготовка уроку з використанням сучасних технологій потребує багато часу для пошуку, систематизації та оформлення інформації. Такі інновації особливо ефективні під час вивчення нового матеріалу, на повторювально-узагальнюючих та інших типах уроків ${ }^{9}$.

Важливо, що презентації можна використовувати на різних етапах уроку з української мови. На етапі актуалізації знань є можливість ілюструвати запитання графічними об’єктами, анімацією, звуковим супроводом, подати кілька слайдів із попередніх уроків із кросвордами, ребусами тощо. На етапі пояснення нового матеріалу використовують фото, аудіо-, відеофрагменти, динамічні таблиці та схеми, інтерактивні моделі, проектуючи їх на великий екран за допомогою мультимедійного проектора. Зазначимо, при цьому істотно змінюється технологія пояснення матеріалу - вчитель коментує інформацію, що з'являється на екрані, за необхідності супроводжуючи іiі додатковими поясненнями та прикладами. Це дає змогу акцентувати на найскладніших та найбільш важливих моментах уроку. На етапі закріплення знань використовуються ілюстровані запитання, завдання для групового або індивідуального виконання, пропонується учням самостійно прокоментувати слайди, які демонструвалися на етапі пояснення нового матеріалу ${ }^{10}$.

Одним iз широко відомих електронних ресурсів, що використовується на уроках української мови, $€$ комп'ютерні тренажери, основною метою яких є створення умов для відпрацювання навичок із вивченої теми. Цей електронний ресурс варто використовувати під час фронтальної та індивідуальної роботи 3 класом («Орфографічні п’ятихвилинки», «Орфографічні дуелі», «Літературне асорті», «Знайди помилку», «Літературна вікторина»). Популярним на уроках української мови серед учнів 5-6 класів $є$ малюнковий диктант, де учні самостійно, з опорою на малюнок, а не на мовлення вчителя, пишуть словникові слова або слова 3 певною орфограмою чи

9 Захарова И.Г. Информационные технологии в образовании : учеб. пособие для студ. высш. пед. учеб. завед. Москва : Академия, 2003. 192 с.

${ }^{10}$ Мороз О. Використання інформаційно-комп'ютерних технологій в початковій школі. Рідна школа. 2014. С. 43-47. 
граматичною ознакою 3 метою візуалізації правильної відповіді виконаного завдання ${ }^{11}$.

Широкого практичного застосування на уроках мови набули динамічні та статичні таблиці. Динамічні таблиці цілком наочно, у динаміці показують, які зміни відбуваються у словах і реченнях. За допомогою цього засобу учні усвідомлюють принцип дії того чи іншого правила, що сприяє активному навчанню мови. Потрібні елементи з'являються i зникають, рухаються, збільшуються, переміщаються, іноді зі звуковим чи анімаційним супроводом. Матеріал підбираємо з орієнтацією на асоціативне та образне мислення учнів, що дає змогу швидко запам'ятати та якісно застосовувати набуті знання. Статичні таблиці вчителі звикли мати в друкованому вигляді. Мультимедійна дошка дає змогу щоразу застосовувати сучасну за дизайном оригінальну таблицю чи схему. Крім того, до такої таблиці завжди можна щось вписати, щось в ній підкреслити і цим самим активізувати увагу школярів. Дуже вдале використання таких таблиць у поєднанні 3 індивідуальними картками, в яких уміщено мовний матеріал для аналізу та схему відповідного мовного розбору. Наприклад, під час закріплення теми «Односкладні прості речення» на таблиці учні спеціальним маркером ставлять розділові знаки, роблять позначки напроти відповідної характеристики речення, не витрачаючи часу на написання і його письмовий розбір. Такий підхід до організації роботи значно економить час і підвищує ефективність навчального процесу, адже за урок можна розібрати не $2-3$ речення, а $10-15^{12}$.

Тестовий контроль із допомогою ЕР дає змогу швидше і об'єктивніше, ніж при традиційному способі, виявити знання і незнання учнів. Цей спосіб організації навчального процесу зручний іпростий для оцінювання в сучасній системі обробки інформації можна відразу подивитися результати. Крім того, використання інтерактивного електронного ресурсу дає змогу вчителю або одному 3 учнів працювати з ним, а іншим брати участь у роботі, яка організована вчителем. У школі комп'ютер стає електронним посередником між вчителем i учнем. Він дає змогу організувати процес навчання за індивідуальною програмою. Учень, який навчається за пультом комп'ютера, може сам вибирати найбільш зручну для нього швидкість

${ }^{11}$ Інформаційні технології в навчанні. Київ : Видавнича група ВНV, 2006. 240 с.

12 Сучасний урок. Інтерактивні технології навчання : наук.-метод. посібник / За ред. О.І. Пометун, Л.В. Пироженко. Київ : А.С.К., 2006. 
подачі і засвоєння матеріалу. У цьому проявляється головна перевага комп'ютера в процесі навчання: він працює 3 кожним учнем окремо ${ }^{13}$.

Отже, з нашої точки зору, використання електронних ресурсів на уроках української мови $\epsilon$ ефективним, оскільки за допомогою сучасного комп'ютера можна об'єднати в одній програмі як текст, анімацію, звук, графіку, так і високоякісні фотозображення, відео, якість якого не поступається телевізійному: при викладенні нового матеріалу - візуалізація знань (демонстраційно-енциклопедичні програми; програма презентацій PowerPoint); закріплення викладеного матеріалу (тренінг - різноманітні навчальні програми); система контролю і перевірки (тестування з оцінюванням, програми контролю); самостійна робота учнів (навчальні програми типу «Репетитор», «Фраза», енциклопедії, розвиваючі програми); за можливості відмова від класно-урочної системи: проведення інтегрованих уроків із застосуванням методу проектів, результатом яких буде створення Webсторінок, проведення телеконференцій, використання сучасних інтернет-технологій; тренування конкретних здібностей учня (увага, пам'ять, мислення і т.д.).

\section{2. Метод проектів із використанням електронних ресурсів на уроках української мови}

Розвитку пізнавальних навичок, критичного мислення, вміння самостійно конструювати свої знання, орієнтуватися в інформаційному просторі, вміння побачити, сформулювати і вирішити проблему сприяє проектна технологія.

Термін «проект» (від лат. Projektus, буквально - кинутий вперед) це спеціально організований учителем (разом з учнями) і самостійно виконуваний учнями комплекс дій iз вирішення нагальних для учня проблем, що завершуються створенням продукту.

Характерними рисами проектного навчання $€$ :

1) актуальність;

2) мотиваційний характер навчання: завдання відповідають рівню учнів і їх інтересам;

3) міждисциплінарний характер навчання: завдання i навчальний матеріал організовується швидше згідно із завданнями, a не дисципліни;

4) достовірність;

5) орієнтація на співпрацю;

6) позитивний настрій.

13 Захарова И.Г. Информационные технологии в образовании : учеб. пособие для студ. высш. пед. учеб. завед. Москва : Академия, 2003. 192 с. 
Основні типи проектів зображено в табл. 1.

Таблиця 1

Основні типи проектів

\begin{tabular}{|c|c|}
\hline Тип проектів & 3міст \\
\hline Інфор маційні & $\begin{array}{l}\text { Спрямований на роботу з інформацією про } \\
\text { певний об'єкт або явища. Для кожного } \\
\text { проекту мають бути визначені: } \\
\text { 1) мета проекту, його актуальність; } \\
\text { 2) джерела інформації (літературні, засоби } \\
\text { 3МІ, бази даних, включаючи електронні, } \\
\text { інтерв'ю); } \\
\text { 3) методи обробки інформації (аналіз, } \\
\text { узагальнення, зіставлення з відомими } \\
\text { фактами, аргументовані висновки); } \\
\text { 4) форми представлення результатів (стаття, } \\
\text { реферат, доповідь, відео та ін.); } \\
\text { 5) види презентації проекту (публікація, в } \\
\text { тому числі в інтернеті, обговорення на } \\
\text { конференції і т.п.) }\end{array}$ \\
\hline Творчі & $\begin{array}{l}\text { Відрізняються чітким плануванням } \\
\text { кінцевих результатів і формами їх уявлення. } \\
\text { Структура проекту розвивається далі в } \\
\text { процесі роботи, виходячи із жанру } \\
\text { кінцевого результату та інтересів учасників, } \\
\text { наприклад спільний відеофільм; } \\
\text { мультимедійний комп'ютерний проект }\end{array}$ \\
\hline $\begin{array}{l}\text { Практико-орієнтовані } \\
\text { (пр икладні) }\end{array}$ & $\begin{array}{l}\text { Ці проекти теж відрізняються чітко } \\
\text { позначеним із самого початку результатом } \\
\text { діяльності його учасників, наприклад } \\
\text { проект закону; електронний довідковий } \\
\text { матеріал }\end{array}$ \\
\hline Дослідницькі & $\begin{array}{l}\text { Рішення творчої, дослідницької проблеми } \\
\text { (завдання) із заздалегідь невідомим } \\
\text { результатом }\end{array}$ \\
\hline
\end{tabular}

Джерело: складено автором на основі [Карташова Л.А. Система навчання інформаційних технологій майбутніх вчителів суспільно-гуманітарних дисциплін : монографія. Луцьк, 2011. 264 с.; Фоміних Н.Ю. Інформаційнокомунікаційні технології у викладанні філологічних дисчиплін : навч.-метод. посібник. Севастополь : Рібест, 2010. 196 с.]

У проектній роботі метою навчання стає, перш за все, розвиток в учнів самостійної активності, спрямованої на освоєння нового досвіду. У результаті iï застосування формуються компетенції у сфері самостійної пізнавальної діяльності, вміння і навички критичного мислення в умовах роботи з великими об'ємами інформації, навички 
роботи в команді. Для роботи над навчальним проектом організовується спільна навчально-пізнавальна, дослідницька, творча або ігрова діяльність учнів-партнерів, що має спільну мету, узгоджені методи, способи діяльності, спрямовані на досягнення загального результату із вирішенням будь-якої проблеми, важливої для учасників проекту.

Для роботи на уроках української мови можна використовувати проекти різних видів: дослідницький, творчий, ігровий, інформаційний, прикладний. Залежно від складності теми в створенні проекту беруть участь всі учні або тільки група учнів (особистісний, парний, груповий проекти). Вчитель може відкрито координувати, приховано направляти роботу учнів або виступати як повноправний учасник проекту.

Роль педагога проявляє себе в організації такої роботи, в процесі і результаті якої проявляються й розвиваються інформаційні компетенції вміння інтегрувати інформацію, визначати інформацію, керувати інформацією, передавати інформацію, оцінювати інформацію, створювати інформацію, робити доступною інформацію. Репродуктивні методи навчання 3 використанням презентацій набувають рис особистісноорієнтованого навчання, при якому кожен учень в індивідуальному темпі вивчає матеріал. У процесі такої роботи вчитель заздалегідь створює електронний посібник (презентацію), і на уроці учні самостійно вивчають новий матеріал, а педагог лише координує роботу, надаючи допомогу школярам ${ }^{14}$.

Перевагами проектних технологій у процесі викладання української мови $\epsilon^{15}$ :

1) застосування методу проектів у навчанні дає змогу сформувати міжпредметні зв'язки в процесі роботи над проектом;

2) проекти дають змогу учням вибрати для підсумкового контролю найбільш цікаву для них тему та форму захисту;

3) метод проектів виховує дослідницьку культуру, розвиває навички естетичного оформлення і презентації результатів своєї праці;

4) використовуючи метод проектів, учитель отримує змогу побачити прихований потенціал дитини, знайти індивідуальний підхід до розкриття інтелектуальних і творчих задатків дитини.

Метод проектів використовують у всіх класах. Звичайно, старшокласники вже знайомі 3 програмами Microsoft Power Point,

14 Методичний порадник: організація та зміст освітньої діяльності у 2019/2020 навчальному році : інформаційно-метод. збірник / за заг. ред. Н.М. Бендерець, О.В. Матушевської. Біла Церква : КНЗ КОР «Київський обласний інститут післядипломної освіти педагогічних кадрів», 2019.

${ }_{15}$ Мороз О. Використання інформаційно-комп'ютерних технологій в початковій школі. Рідна школа. 2014. С. 43-47. 
Microsoft Publisher, Microsoft Word, учням середньої школи потрібно ще оволодіти азами комп'ютерної грамоти, але витрачені зусилля обов'язково окупляться.

У результаті учні поспішають на такі уроки, чекають їх із нетерпінням, пропонують нові ідеї. Після проведеної роботи школярі можуть самостійно створювати інформаційні проекти і надавати допомогу в підготовці та проведенні уроків.

\section{3. Онлайн-інструменти для викладання української мови}

Здійснивши дослідження та аналіз наукової літератури, виділимо основні онлайн-інструменти, які можуть бути використані на різних етапах організації заняття $з$ української мови ${ }^{16}$.

1. «Ребуси № 1»- українськомовна онлайн-платформа, за допомогою якої можна створювати власні ребуси чи розгадувати наявні на сайті (рис. 4).

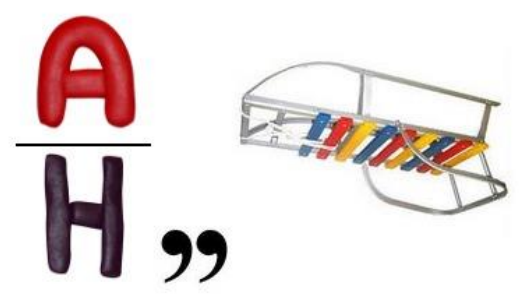

Рис. 4. Приклад дитячого ребуса (відповідь: ананас)

Основними перевагами «Ребуси №1» є:

- генератор ребусів дає змогу зашифрувати окреме слово або речення українською, російською чи англійською мовами;

- довідкова інформація про символи, за допомогою яких створюються головоломки, та історії складання ребусів;

- пояснення принципів побудови та секретів розгадування ребусів;

- генерування головоломок відповідно до рівня складності (для учнів молодшої, середньої або старшої школи).

2. LearningApps - це сервіс, який призначений для створення інтерактивних навчально-методичних вправ із різних предметів, у т.ч. 3 української мови. Тематика різноманітна: від роботи 3 картами до

16 Дев'ять онлайн-інструментів для організації цікавих практичних робіт зі школярами. URL: https://naurok.com.ua/post/9-onlayn-instrumentiv-dlya-organizacicikavih-praktichnih-robit-zi-shkolyarami (дата звернення: 25.01.2020) 
розв'язування кросвордів i створення карт знань. Їх можна використовувати в роботі 3 інтерактивною дошкою або як індивідуальні вправи для учнів. Там знаходиться база завдань, розроблених учителями 3 різних країн для усіх предметів шкільної програми. Кожен із ресурсів можна використати на своєму уроці, змінити під власні потреби, розробити схожий чи зовсім інший навчальний модуль (рис. 5) ${ }^{17}$.

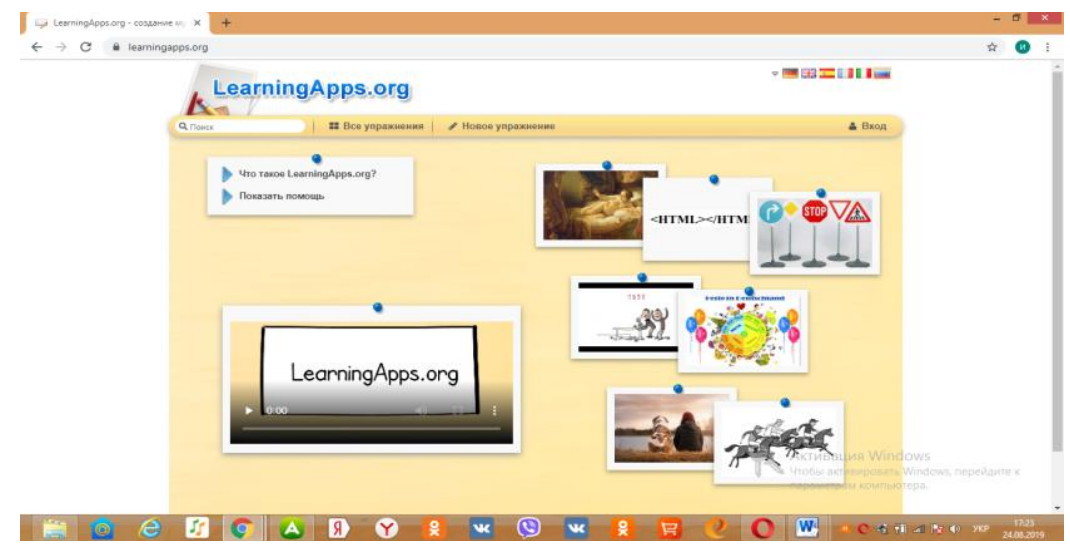

Puc. 5. LearningApps

3. Онлайн-інструмент Trello - гнучкий, візуальний інструмент для спільного управління проектами та завданнями. Інтерфейс базується на віртуальних дошках. Такий інструмент корисний для розподілу завдань за деякими типами: заплановані та поточні. Під час уроку з української мови учні зможуть бачити, які завдання вони зробили, а які ще треба буде доробити. Trello легко адаптується до проектів, команди $\mathrm{i}$ навчального процесу (рис. 6) ${ }^{18}$.

17 Онлайн-інструмент Learning Apps. URL: https://learningapps.org (дата звернення: 25.01.2020)

18 Онлайн-інструмент Trello. URL: https://trello.com/ (дата звернення: 25.01.2020). 


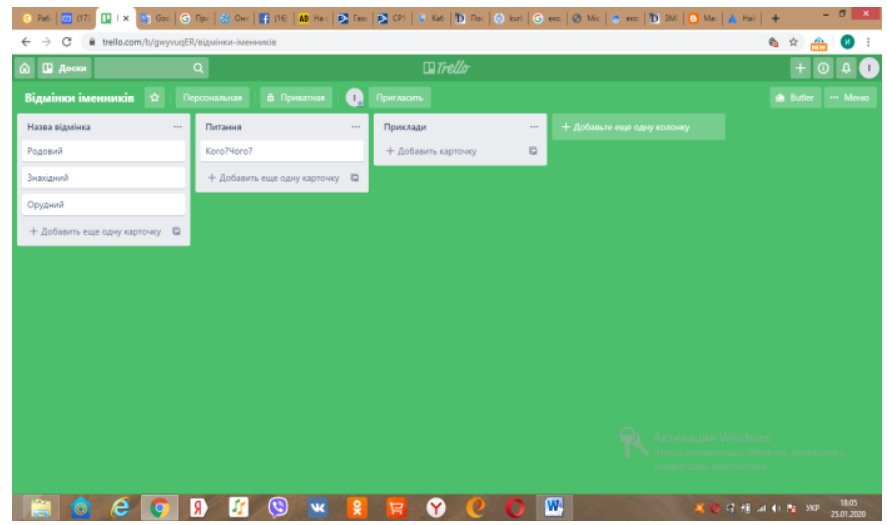

Рис. 6. Приклад використання Trello

4. Онлайн-інструмент Padlet призначений для створення та наповнення контентом віртуальної дошки (простору) 3 можливістю спільного редагування (рис. 7) ${ }^{19}$. Цей сервіс можна назвати платформою для ідей, мозкових штурмів тощо. Якщо порівняти можливості звичайної інтерактивної дошки або папірців із написами та віртуальну інтерактивну дошку, де учні, працюючи з нею у процесі виконання запропонованого завдання, мають змогу одночасно бачити результати роботи інших груп, одразу їх аналізувати і дійти згоди зі спірних питань у режимі онлайн.

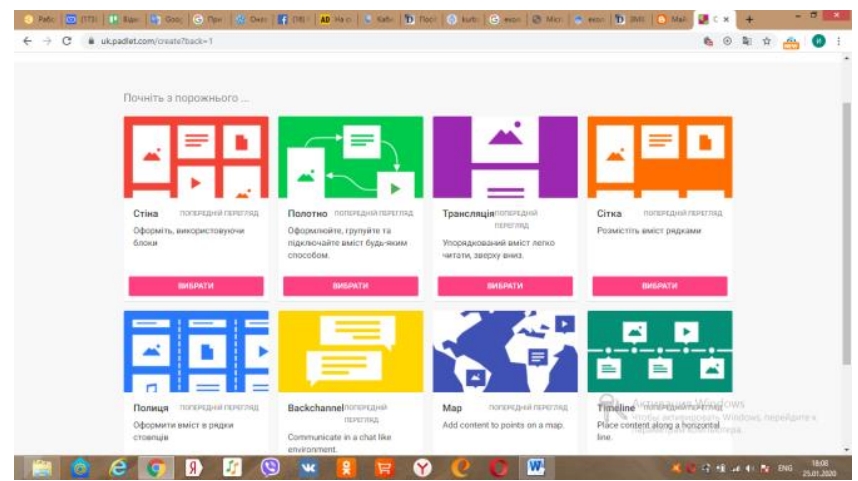

Рис. 7. Приклад використання Padlet

19 Онлайн-інструмент Padlet. URL: https://uk.padlet.com/dashboard (дата звернення: 25.01.2020). 
Серед усього різноманіття онлайн-інструментів, що можна використовувати 3 будь-якого гаджету, підключеного до мережі Інтернет під час занять 3 української мови, самостійної роботи та для підвищення мотивації до навчання учнів, варто виокремити онлайнсервіс Learning Apps. Платформа є одним із хмарних сервісів веб 2.0 для організації та підтримки освітніх процесів та безплатним міжнародним відкритим освітнім ресурсом, що містить як представлені в режимі загального доступу навчальні готові навчальні матеріали (завдання-модулі; тести-модулі), так і конструктор для самостійного виробництва нових інтерактивних навчально-методичних матеріалів ${ }^{20}$.

Таким чином, уроки з використанням електронних ресурсів стають звичними для учнів, а для вчителів - нормою роботи, що, на наш погляд, $\epsilon$ одним із важливих результатів інноваційної роботи в сучасній освіті.

\section{ВИСНОВКИ}

Можна зробити висновок, що в результаті використання електронних ресурсів на уроках української мови відбувається: підвищення ефективності навчання (розвиток інтелекту школярів і навичок самостійної роботи 3 пошуку інформації; різноманітність форм навчальної діяльності дітей на уроці); здійснення індивідуального підходу в навчанні (самостійна робота 3 оптимальною для себе швидкістю); розширення обсягу навчальної інформації; забезпечення гнучкості управління навчальним процесом (відстеження процесу і результату своєї роботи); поліпшення організації уроку (дидактичний матеріал завжди $є$ в достатній кількості); підвищення якості контролю знань учнів i різноманітність його форми; включення дітей у колективну діяльність у парах, групах; підвищення інтересу дитини до вивчення предмета $і$ до навчання загалом, поліпшення якості освіти, активізація творчого потенціалу учня і вчителя; включення школярів іпедагогів у сучасний простір інформаційного суспільства, самореалізація і саморозвиток особистості учня.

Тому ми впевнені, що електронні ресурси на уроках української мови, втім, як і на будь-яких інших уроках, не тільки можливі, але і необхідні. Наші діти - це покоління візуалів, хочемо ми того чи ні, але вони звикли отримувати інформацію 3 моніторів i дисплеїв. У результаті застосування ЕР істотно розширює можливості сучасного уроку, адже дуже важливо не зупинятися на місці, ставити нові цілі іпрагнути до їх досягнення - це основний механізм розвитку особистості як учня, так і вчителя.

20 Гладун М.А., Сабліна М.А. Сучасні он-лайн інструменти інтерактивного навчання як технологія співробітництва. Open educational e-environment of modern University. 2018. № 4. С. 33-43. 


\section{АНОТАЦІЯ}

У статті висвітлено особливості використання електронних ресурсів у процесі викладання української мови. Зазначено переваги та недоліки використання електронних ресурсів на уроках. Визначено складники інтенсифікації процесу навчання у процесі викладання української мови 3 використанням електронного ресурсу. Виокремлено основні дидактичні функції, які реалізуються за допомогою комп'ютера на уроках української мови. Зазначено, що використання електронних та мультимедійних ресурсів на уроках української мови дає простір для реалізації можливостей кожної дитини, робить навчання успішним і комфортним, особистісно-орієнтовним і мобільним, а також оптимізує навчальний процес. Наведено широко відомі електронні ресурси, що використовується на уроках української мови: презентації, комп'ютерні тренажери, динамічні та статичні таблиці. Розкрито переваги впровадження методу проектів із використанням електронних ресурсів на уроках української мови. Відібрано онлайн-інструменти, які можуть бути використані на різних етапах організації заняття з української мови.

\section{ЛIТЕРАТУРА}

1. Гладун М.А., Сабліна М.А. Сучасні он-лайн інструменти інтерактивного навчання як технологія співробітництва. Open educational e-environment of modern University. 2018. № 4. C. 33-43.

2. Гримальська А.О. Використання можливостей інформаційнокомунікаційних технологій для підвищення якості навчання української мови і літератури. Таврійський вісник освіти. 2016. № 4 (56). С. 23-27.

3. Гулак О.А. Роль сучасних комп'ютерних та педагогічних технологій у підвищенні ефективності та результативності урочної діяльності учнів. URL:http://ru.osvita.ua/school/lessons_summary/ edu_technology/44358/ (дата звернення: 24.01.2020).

4. Дев'ять онлайн-інструментів для організації цікавих практичних робіт зі школярами. URL: https://naurok.com.ua/post/9-onlayninstrumentiv-dlya-organizaci-cikavih-praktichnih-robit-zi-shkolyarami (дата звернення: 25.01.2020)

5. Дементієвська Н.П., Морзе Н.В. Компютерні технології для розвитку учнів та вчителів. Інформачійні технології $і$ засоби навчання : збірник наук. праць. Київ : Атака, 2005. С. 76-95.

6. Захарова И.Г. Информационные технологии в образовании : учебник пособ. для студ. высш. пед. учеб. завед. Москва : Академия, 2003. 192 c.

7. Зиньковська 3.О. Психолого-педагогічні аспекти використання мультимедійних засобів навчання. Класному керівнику для роботи. 2013. № 7(55). С. 6-12.

8. Інформаційні технології в навчанні. Київ : Видавнича група BHV, 2006. 240 c. 
9. Карташова Л.А. Система навчання інформаційних технологій майбутніх вчителів суспільно-гуманітарних дисциплін : монографія. Луцьк, 2011. 264 с.

10. Методичний порадник: організація та зміст освітньої діяльності у 2019/2020 навчальному році : інформаційно-метод. збірник / за заг. ред. Н.М. Бендерець, О.В. Матушевської. Біла Церква : КНЗ КОР «Київський обласний інститут післядипломної освіти педагогічних кадрів», 2019.

11. Мороз О. Використання інформаційно-комп'ютерних технологій в початковій школі. Рідна школа. 2014. С. 43-47.

12. Ніколаєнко T.M. Використання IKT на уроках української мови та літератури. URL: https://vseosvita.ua/library (дата звернення: 19.01.2020).

13. Онлайн-інструмент Padlet. URL: https://uk.padlet.com/dashboard (дата звернення: 25.01.2020)

14. Онлайн-інструмент Trello. URL: https://trello.com/ (дата звернення: 25.01.2020)

15. Онлайн-інструмент LearningApps. URL: https://learningapps.org (дата звернення: 25.01.2020)

16. Орлова О.I. Компетентнісне навчання за допомогою IКT на уроках української мови та літератури. URL: http://5fan.ru/download.php (дата звернення: 20.01.2020).

17. Сороко Н.В. Дидактичні функції інформаційних i комунікаційних технологій у професійній діяльності вчителя-словесника. URL: http://www.nbuv.gov.ua/e-journals/ITZN/em5/emg.html (дата звернення: 22.01.2020).

18. Сучасний урок. Інтерактивні технології навчання : наук.-метод. посібник / За ред. О.І. Пометун, Л.В. Пироженко. Київ : А.С.К., 2006.

19. Фоміних Н.Ю. Інформаційно-комунікаційні технології у викладанні філологічних дисциплін : навч.-метод. посібник. Севастополь : Рібест, 2010. 196 с.

20. Шелехова Г. Використання комп'ютерних технологій на уроках української мови. Украӥнська мова і література в школі. 2006. № 8. C. $4-8$.

\section{Information about the author:} Ilchuk V. V.,

Candidate of Pedagogical Sciences, Department of Methodology of Philological Disciplines and Stylistics of the Ukrainian Language Faculty of Philology and Journalism named after Michael Stelmakh Vinnytsia Mykhailo Kotsiubynskyi State Pedagogical University 32, Os trozhskogo str., Vinnitsa, 21001, Ukraine 